Tulowitzki, Pierre; Bremm, Nina; Brown, Chris; Krammer, Georg

\title{
Using insights from video games to support formal education. A conceptual exploration
}

Die deutsche Schule 111 (2019) 4, S. 405-421

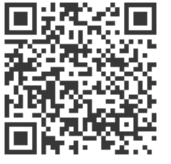

Quellenangabe/ Reference:

Tulowitzki, Pierre; Bremm, Nina; Brown, Chris; Krammer, Georg: Using insights from video games to support formal education. A conceptual exploration - In: Die deutsche Schule 111 (2019) 4, S. 405-421 URN: urn:nbn:de:0111-pedocs-206096 - DOI: 10.25656/01:20609

https://nbn-resolving.org/urn:nbn:de:0111-pedocs-206096

https://doi.org/10.25656/01:20609

in Kooperation mit / in cooperation with:

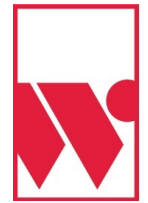

\section{WAXMANN}

www.waxmann.com

http://www.waxmann.com

\section{Nutzungsbedingungen}

Gewährt wird ein nicht exklusives, nicht übertragbares, persönliches und beschränktes Recht auf Nutzung dieses Dokuments. Dieses Dokument ist ausschließlich für den persönlichen, nicht-kommerziellen Gebrauch bestimmt. Die Nutzung stellt keine Übertragung des Eigentumsrechts an diesem Dokument dar und gilt vorbehaltlich der folgenden Einschränkungen Auf sämtlichen Kopien dieses Dokuments müssen alle Urheberrechtshinweise und sonstigen Hinweise auf gesetzlichen Schutz beibehalten werden. Sie dürfen dieses Dokument nicht in irgendeiner Weise abändern, noch dürfen Sie dieses Dokument für öffentliche oder kommerzielle Zwecke vervielfältigen, öffentlich ausstellen, aufführen, vertreiben oder anderweitig nutzen.

Mit der Verwendung dieses Dokuments erkennen Sie die Nutzungsbedingungen an.

\section{Terms of use}

We grant a non-exclusive, non-transferable, individual and limited right to using this document.

This document is solely intended for your personal, non-commercial use. Use of this document does not include any transfer of property rights and it is conditional to the following limitations: All of the copies of this documents must retain all copyright information and other information regarding legal protection. You are not allowed to alter this document in any way, to copy it for public or commercial purposes, to exhibit the document in public, to perform, distribute or otherwise use the document in public.

By using this particular document, you accept the above-stated conditions of use.

\section{Kontakt / Contact:}

\section{peDOcs}

DIPF | Leibniz-Institut für Bildungsforschung und Bildungsinformation Informationszentrum (IZ) Bildung

E-Mail: pedocs@dipf.de

Internet: www.pedocs.de

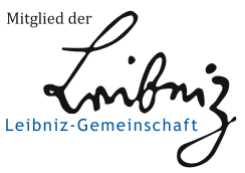


Pierre Tulowitzki, Nina Bremm, Chris Brown \& Georg Krammer

\title{
Using Insights from Video Games to Support Formal Education - A Conceptual Exploration
}

\begin{abstract}
This article draws upon findings from research on the effects of gaming, educational psychology, teacher professionalism as well as school improvement, to develop a framework for linking video game activities to formal education. This framework uses video game achievements - virtual trophies received for completing tasks or mastering challenges as a proxy indicator for the development of competencies relevant to formal education. We suggest that this knowledge can be harnessed to improve teaching and learning, in particular teacher perceptions, teaching skills, and, ultimately, measurable changes in students' learning. Showing teachers what students can actually do and are already doing (in video games) could help them better understand areas of strength and interest of their students.

Keywords: video games, video game achievements, asset-based orientation, schools in challenging circumstances, professional development
\end{abstract}

\section{Die Nutzung von Erkenntnissen aus Videospielen für den formalen Unterricht - eine konzeptionelle Annäherung}

\section{Zusammenfassung}

Der Beitrag führt Erkenntnisse aus der Erforschung der Wirkung von Computerspielen, der Psychologie sowie der Schulentwicklungsforschung zusammen, um Ansätze eines Konzepts zur Nutzung von Daten aus Videospielen zur Unterstützung von formalen Lehr-Lernsettings zu präsentieren. In diesem Ansatz werden Daten basierend auf sogenannten "Achievements" - virtuellen Auszeichnungen oder Trophäen in Videospielen - als Behelfsindikatoren für die Entwicklung von für die formale Bildung relevanten Kompetenzen genutzt. Derartiges Wissen könnte u.a. dazu genutzt werden, LehrLernsettings zu unterstützen, z.B. durch veränderte Perspektiven der Lehrkräfte auf die Fähigkeiten von Schüler*innen. Wissen um Kompetenzen von Kindern und Jugendlichen (aus Videospielen) könnte Lehrkräfte dabei unterstützen, eine kompetenzorientierte Perspektive auf Schüler*innen zu entwickeln, welche sich letztendlich messbar auf den Lernerfolg in formalen Lehr-Lernsettings niederschlagen könnte. 
Pierre Tulowitzki, Nina Bremm, Chris Brown \& Georg Krammer

Schlüsselwörter: Videospiele, Achievements, Schulen in herausfordernder Lage, Unterricht, Weiterbildung

\section{Introduction}

Video games are a ubiquitous feature in the lives of today's children and teenagers (Ofcom, 2017; Waller, Willemse, Genner, Suter \& Süss, 2016). Yet, research on the effects of playing video games is still a relatively young field and one which, to date, has predominantly been focused on potential risks (Ferguson, 2015). More recently, however, understanding the benefits of video games has emerged as a field of research in its own right (Granic, Lobel \& Engels, 2014), with indications of video games being potent tools for learning and for training certain cognitive and social abilities (for instance, self-regulation, spatial thinking, visual processing and cognitive control; see for example Barr, 2017; Gabbiadini \& Greitemeyer, 2017; Granic et al., 2014; Oei \& Patterson, 2014).

This article draws upon findings from the effects of gaming, educational psychology, teacher professionalism as well as school improvement research to develop a proposal for linking activities associated with video games to formal education. The core idea is that teachers could be made aware of the competencies students train in video games that are also relevant for formal education.

The goal behind the proposed model is to make data from video game activities usable for supporting formal education practice, without impeding on the privacy or sovereignty of adolescents. We argue that students' video game activities can be linked to predominant models of cognitive abilities (Cattell-Horn-Carroll theory of cognitive abilities; cf. McGrew, 2009), with these abilities in turn being relevant for academic achievement (Deary, Strand, Smith \& Fernandes, 2007). We then suggest developing tools that support teachers in understanding the competences their students have trained through video games, which are relevant for formal learning. While greater knowledge about competencies used and developed by children playing video games could support all children's learning, it could be especially beneficial for children from schools in areas with low socioeconomic status (SES), where: 1) a strong lifeworld orientation and positive beliefs towards students' cognitive and academic abilities seem to be critical for educational success (Bremm, 2019); and 2) crucially, children spend more time playing video games (Carson, Spence, Cutumisu \& Cargill, 2010).

Following such an approach raises ethical questions about the extent to which the activities that children and teenagers carry out in their spare time should be 'used' for formal education purposes. Oriented on the discourse on informal and non-for- 
mal learning settings and their potential for formal educational processes - especially for disadvantaged children - our aim is to explore the possibilities that leisure gaming can offer for school education. It is important to note that this approach does not provide teachers with direct information about the actual gaming behavior of their students. Rather, our aim is to establish a framework that allows teachers to gain insights into the competencies that students develop and train while playing video games in their leisure time. This could help to challenge common stereotypes and deficit perspectives around gaming and around a lack of competencies and skills from students from disadvantaged communities.

\section{Effects of playing video games on children - a brief overview}

Studying the effects of playing video games has long been a contested area of research. Findings from several early meta-analyses suggest that playing video games can increase aggressive behavior in children and young adults (Anderson \& Bushman, 2001; Anderson et al., 2010). More recent meta-analyses (Ferguson, 2015) and studies with randomized experimental conditions (Valadez \& Ferguson, 2012), however, paint a different picture, concluding that there are either no such harming effects, or that any effect sizes found are virtually insignificant.

By contrast, research into potential benefits of gaming suggests that playing, for example, pro-social video games increases pro-social behavior (Greitemeyer \& Mügge, 2014). Similarly, so called active video games (video games which involve physical activity) increase players' fitness (Peng, Lin \& Crouse, 2011; Primack et al., 2012). From a pedagogical point of view, one conclusion to draw from these observed benefits is that children playing video games learn and train various skills, with the exact nature of what is learned depending on the game type. This view is supported by a sizeable body of research. For example, in their review of research, Granic et al. (2014) conclude that video games hold tremendous potential for learning. This conclusion is further supported by findings from a number of studies (for instance Baniqued et al., 2013; Barr, 2017; Moisala et al., 2017). Several scholars have called for video games to be recognized (and used) as learning tools (Gee, 2005; Shaffer, Squire, Halverson \& Gee, 2005).

It is also noted that studies such as Green's and Bavelier's (2012) on cognitive development in video gamers, or Kühn's, Gleich's, Lorenz', Lindenberger's and Gallinat's (2014) on the development of cerebral structural plasticity (as indicators for cognitive development) indicate that the use of video games produces change even at the structural level of the brain: 
"Video game training augments GM [gray matter] in brain areas crucial for spatial navigation, strategic planning, working memory and motor performance going along with evidence for behavioral changes of navigation strategy" (Kühn et al., 2014, p. 1).

These findings are more contested, however, with some (meta-)reviews finding a clear, significant connection (Bediou, Adams, Mayer, Tipton, Green \& Bavelier, 2018; Pallavicini, Ferrari \& Mantovani, 2018) and others concluding that cognitive ability and video game skill are only weakly related (Roque \& Boot, 2018; Sala, Tatlidil \& Gobet, 2018).

In addition, video games appear to be not only a potential tool for learning, but also for assessment. For instance, recent research (Boot, 2015; Landers, 2014) suggests that testing with video games is more motivating than more traditional methods (Quiroga, Román, De La Fuente, Privado \& Colom, 2016). This is because video games often include an engaging narrative and consider new challenges or elements as players complete levels in the game.

Attempts to utilize games for educational purposes has led to a large body of research on so-called "serious games". Serious games walk the line between fostering learning - to be "serious" - and retaining their engaging and entertaining value - to be "games" (Arnab et al., 2015, p. 2). While the effectiveness of serious games has yet to be shown consistently (Giessen, 2015; Girard, Ecalle \& Magnan, 2012), recent systematic reviews found it useful to contrast serious games to entertainment games and point to a variety of learning outcomes for serious games (Boyle et al., 2016). The variety of learning outcomes has been classified into knowledge acquisition, skill acquisition, perceptual and cognitive, physiological, affective, behavior change, and social and soft skills.

Synthesizing this large body of evidence on serious games may be done by mapping learning mechanics to game mechanics to address the underlying mechanics of learning (Arnab et al., 2015). On the one hand, this mapping offers a useful framework for classifying games and their integrated learning mechanics. On the other hand, the theoretical rationale only tentatively taps into these fundamental individual differences among students, which are strongly related to academic achievement. Therefore, an avenue worth exploring may be to relate (serious) games to individual differences students train in video games that are also relevant for formal education, and thereby ultimately for academic achievement. For example, scholars have found that games associated with working memory and reasoning are related to facets of general mental ability (Baniqued et al., 2013). General mental ability in turn has been postulated as an antecedents for academic achievement (Deary et al., 2007). 
The concept of using mechanics from games as motivational tools has also found its way into education under the term "gamification" (Dicheva, Dichev, Agre \& Angelova, 2015). Fueled by the possibilities of digitization, it has been advocated to incorporate elements of gaming known to affect motivation into educational systems (for a critical review, see Buck, 2017). From a critical point of view, such "gamification" has only limited evidence of success (Dicheva et al., 2015), with some scholars criticizing the forced nature of this type of approach (Bogost, 2014; Devers \& Gurung, 2015).

Serious games and gamification form a large body of literature on what we know today on how to use games to foster learning. Their shared basis is that common practices of learning are either augmented or enhanced by the possibilities of digitization. In essence, these approaches offer possibilities to rethink how formal learning is implemented. In doing so, however, students' existing use of games in their every-day life is left untouched. A more promising avenue - we argue - is to understand how children playing video games of their own volition can be useful for formal education. Key to this, we believe, is understanding the nature of video game achievements.

\section{Video game achievements}

As noted by Lewis, de Salas \& Wells (2013), video games can generally be considered as representing a series of ongoing challenges to be faced by a player (or players). In addition to the intrinsic reward players experience from mastering these challenges, many games provide additional rewards in relation to the completion of specific tasks, or in terms of a particular style of gameplay (ibid.). This additional reward is typically an extrinsic reward, referred to as 'achievement'; with other names for such rewards including 'badges', 'reward', 'accomplishments' and 'trophies' (Castillo, Escribano \& Muntada, 2017; Ifenthaler, Bellin-Mularski \& Mah, 2016; Lewis et al., 2013). We propose that such achievements may be used for pedagogical purposes.

Researchers in the area of gaming are increasingly interested in examining the relationship between video games and the development of transferable skills (Castillo et al., 2017). Since achievements represent the demonstration of certain competencies that are required to unlock the reward in question (Ifenthaler et al., 2016), some suggest these achievements can represent recognition of more objective skill development (Castillo et al., 2017; Ifenthaler et al., 2016). In other words, they are indicative of skills that could potentially be transferred from the gaming environment to other aspects of life, i. e. formal education.

In Germany (as well as many other Western countries), expectations of children in terms of education are mostly set through competence-oriented standards. In other words, there is a notion of what children should be able to know and to do at a cer- 
tain age. In video games, this definition of what is necessary to be performed in certain situations already exists in the form of achievements. In many cases, the achievements are presented to the player as a list of objectives (see Fig. 1).

Fig. 1: Examples of achievements in a video game

\section{Example: Starcraft II}

Starcraft II (Blizzard, 2010) is well defined in Avontuur and Spronck (2013) as "a real-time strategy game where the players' goal is to destroy their enemy's base by developing their own base and an army. Players can choose from three different races to play, each of which has its own features and requires a different way of being played for maximal impact. To construct buildings and produce army units, a player needs to secure minerals, gas and time. During the game, players unlock new options by constructing particular buildings" (p. 3). As time passes in the game, the resources that the player uses to manufacture units or buildings, are consumed, forcing the player to look for other resources on the map or to attempt to overwhelm the opponents before the resources run out.

Exemplary achievements within the game:

"Speed Too!”, “Zerg Rush" \& "Hostbusters"

Definition: Complete the final mission of each story campaign on hard difficulty in less than 25 minutes each.

To get these achievements, a player has to win a game with all three different races under a strict time-limit. As each race has its own particularities (e.g. different units, costs, tactical strengths and weaknesses, different modes of resource exploitation), players have to understand these particularities sufficiently well to win. This implies that they need to make use of the following competencies:

- Fluid Reasoning: the ability to combine pieces of information to form general rules or conclusions and/or to apply general rules to specific problems to produce answers that make sense.

- Reaction and Decision Speed: the ability to make decision at and respond to the onset of simple stimuli.

- General (Domain Specific) Knowledge: knowledge of the three races, their similarities and their differences.

- Short Term Memory: the ability to generate, store, retrieve, and transform visual images and sensations.

- Auditory Processing: perception of auditory information and the ability to distinguish between competing auditory information, as well as analyze and comprehend sound patterns.

- Processing Speed: the ability to perform elementary cognitive tasks with high mental efficiency (cf. attention).

- Management of Material Resources: obtaining and seeing to the appropriate use of equipment, facilities and materials needed to do certain work.

- Problem Sensitivity: accuracy in making decisions about which buildings and troops players should invest their resources in.

- Time Management: the constant, effective managing of time and actions in order to defeat one's opponent.

- Monitoring Self \& Others: the ability to monitor one's self and being able to recognize what is wrong with a strategy and how it can be improved.

- Organizational Skills: the ability to use one's time, energy, resources, etc., in an effective way so achieving what is required.

- Creativity: the ability to come up with unusual or clever ideas about a given topic or situation, or to develop creative ways to solve a problem. 


\section{How can video game achievements be related to academic achievement?}

On the psychological level, it can be concluded that any action demands or requires a series of cognitive processes. Some actions, such as cycling or driving, can stimulate simpler or even procedural cognitive processes. But other actions, such as managing an entire process of producing a product with a team of people behind it, may require great mental effort and skills. In today's work context as well as civil life, there is a virtually infinite number of actions that fall between the minimum and the maximum range of mental stimulation. Video games can mirror this, albeit with a much lower level of complexity.

General mental ability has been shown to be the best predictor of academic achievement. For example, Deary et al. (2007) found a latent correlation of .81 for general mental ability and academic achievement in secondary education. Other scholars (McGrew, 2009) have suggested that the effect of general mental ability on academic achievement may be understood as a mediating effect of broad (e.g. processing speed) and narrow (e.g. reading speed) cognitive abilities.

For studying cognitive abilities, the Cattell-Horn-Carroll theory of cognitive abilities (CHC theory) has been proposed as a common theoretical framework (for an overview, see McGrew, 2009). The CHC theory proposes one overall factor for cognitive abilities - general mental ability - and typically recognizes up to nine broad abilities, which in turn can be differentiated into narrow cognitive abilities. While there is still an ongoing discussion on the nature of cognitive abilities, the CHC theory: 1) provides a framework that combines some of the most prominent theories of cognitive abilities, 2) can serve as a bridge for the theory-to-practice-gap in intelligence research, and 3) has been shown to be useful in applied fields such as school psychology.

We suggest that attaining certain video game achievements may be related to academic achievement: 1) by being a useful proxy indicator for selected cognitive abilities, and 2) by training selected cognitive abilities. The example described above (see Fig. 1 on the previous page) illustrates that a wide range of broad and narrow cognitive abilities are needed to attain certain video game achievements. For example, reasoning skills are absolutely necessary. Reasoning skills, in turn, are conceptualized as fluid reasoning in the $\mathrm{CHC}$ theory, which has often been reported as the broadest cognitive ability most saturated by general mental ability (e.g. Bickley, Keith \& Wolfle, 1995). Studies on alternative modes of testing the broad cognitive ability processing speed offer further indications that there is a link between video game achievements and cognitive abilities. For example, Mcpherson and Burns (2005) demonstrated that a computer-based mouse response (CBMR) test could be used to measure processing speed the same as traditional paper-and-pencil (PP) tests. 
Finally, we suggest that there may be a link between video game achievements and academic achievement above and beyond cognitive abilities. A myriad of non-cognitive abilities have been linked to academic achievement. For example, the personality trait conscientiousness has been shown to be the best predictor of academic achievement above and beyond general mental ability (Poropat, 2009). Other non-cognitive traits have been linked to academic achievement as well, such as the following: motivation factors (e.g. performance goal orientation), self-regulatory learning strategies (e.g. effort regulation), and psychosocial contextual influences like goal commitment (for an overview, see Richardson, Abraham \& Bond, 2012). Building upon these noncognitive abilities, we suggest that to attain certain video game achievements, selected non-cognitive abilities are also essential as players need to systematically coordinate their effort over a long period of time to achieve their goal.

\section{Expectations and assessment of learner achievement}

While acknowledging the critique of a risk of school "annexing" the leisure time of children (Fölling-Albers, 2000) for formal education purposes, we nonetheless posit that being able to connect experiences and competencies from the life-world of children to the context of formal education offers significant potential in terms of motivation and ultimately student performance. It also offers a chance at a fairer assessment of student mental abilities and ultimately at reducing tertiary origin and discrimination effects (Esser \& Hoenig, 2018; Helbig \& Morar, 2018). Research into teachers' judgements indicates that their assessments of students' abilities can be influenced by demographic and socially constructed categories such as gender, ethnic background and even a child's first name (cf. Bonefeld \& Dickhäuser, 2018; Kaiser, Möller, Helm \& Kunter, 2015). Studies also show that factors such as motivation, resilience and learner persistence vary between students from different social backgrounds (cf. summary Ditton, 2016). It is precisely these latter factors that can influence teachers' assessments of student performance (Lorenz, Gentrup, Kristen, Stanat \& Kogan, 2016). The so-called "cooling out processes" (Goffman, 1961) that describe declining educational aspiration, motivation, persistence and a disruption to the formation of a positive academic self-concept, can reinforce inequality effects for students who have experienced repeated failures throughout their schooling. Studies report strong correlations between building positive relationships and high expectations towards students' abilities (positive student orientation) and successful learning in disadvantaged schools (e.g. Racherbäumer, 2017). There are strong indications that such high expectations and positive student orientation are lacking in disadvantaged schools due, for example, to teachers having a deficit-orientation towards students' abilities (Bremm, 2019). Similarly, Sorhagen (2013) highlights interactions between misperceptions of children's abilities in third grade and their measured attainment by the age of 15 . When the ability of early-years students was underestimated in com- 
parison with measured performance, students had lower attainment in mathematics, reading, vocabulary and verbal reasoning by the ninth grade. Furthermore, inaccurate assessment by teachers at the third-grade level had a strong influence on the educational development of students from socially disadvantaged backgrounds (Sorhagen, 2013). Against this background, teachers' better understanding of students' abilities seems crucial for reducing the production and reproduction of social inequalities in educational institutions. To this end, it may prove useful to highlight to teachers that their students' leisure activities, such as gaming, can be related to antecedents of academic achievement. This may be even more the case when this relation is embedded in an evidence-based framework for cognitive development such as the $\mathrm{CHC}$ theory. We suggest that video game achievements hold great potential in this context and that knowledge derived from achievements could be made available for teachers without any extra effort of data collection on their part.

\section{Making achievements useful for teaching and learning}

Following the premises, that 1) video games can lead to learning; and that 2) parts of what abilities are demonstrated in video games (e.g. facets of general mental ability) might also be relevant to formal education, we argue that what has been learned in video games needs to be made visible to teachers in ways that have practical application and relevance. Such an approach would make it easier for teachers to see students' competencies and potential that might not be visible otherwise. Findings from a school improvement project that supported 40 schools in disadvantaged areas in Germany by using data on school quality measures and students' characteristics show that in many schools, it seemed crucial to challenge common stereotypes and deficit orientations amongst teachers towards their students. This then facilitated a situation where change within the schools was possible (Drucks, Bremm, van Ackeren \& Klein, 2019). Specifically, data on students' abilities and competencies helped teachers to question and reflect on their perceived - often underestimated - impact on students' learning due to students' social disadvantage (Valencia, 1997).

With regards to education, however, the challenge is to be able to understand how achievements and the competencies required to unlock these can be recognized and used by teachers in order to enhance teaching and learning. In other words, if achievements can be thought of as indicative of an acquisition (e.g. of a skill or form of cogitative development or social/interpersonal knowhow); if the actions necessary for obtaining them are clear and transparent; and if the competencies associated with the achievement can be inferred and translated in a way that teachers understand, then teachers can be presented with insights into previously unseen aspects of their students' abilities. As a result, teachers can be supported to use this wider understanding in order to enhance teaching and learning. This may be particularly im- 
portant in relation to children from disadvantaged areas. As such, better understanding of achievements that, in turn, can facilitate better relationships and raise teacher expectations regarding these students' abilities is likely to have a positive impact on some of the factors related to successful learning in disadvantaged schools.

For many games and platforms, information about achievements can be exported and analyzed through so-called standardized application program interfaces (APIs). Therefore, a new kind of software tool could be developed that could access and analyze the achievement data and "translate" it into information relevant for teachers. Thus, teachers would not have direct access to the achievement data, but merely to a "cognitive skill translation". This would not only protect the privacy of children, but also save the teachers from having to learn a video game context. The use of the cognitive skill translation tool would be accompanied by training, so that teachers would know about the uses and limits of such a tool (see Fig. 2).

Fig. 2: Model for using video game achievements for formal education

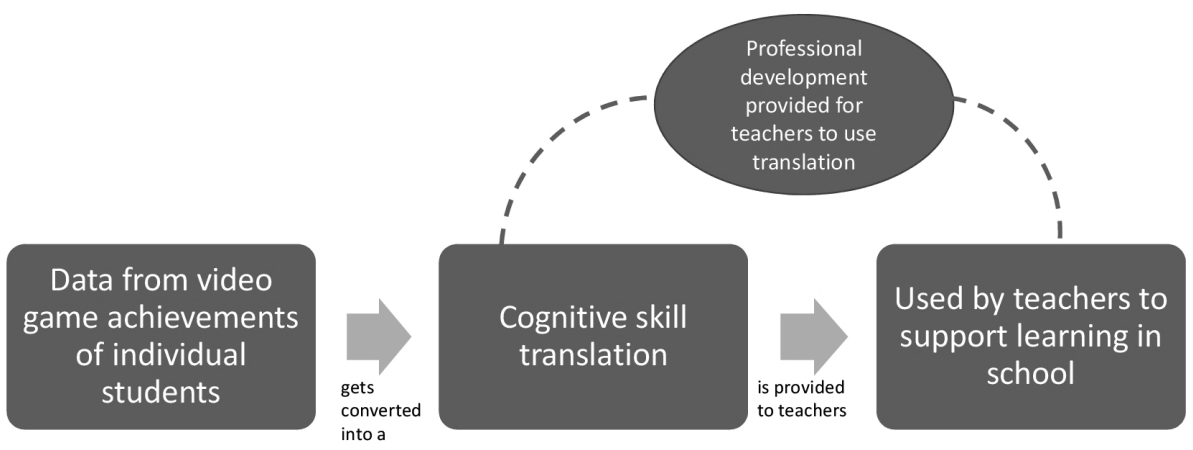

An example of how this could look like would be as follows: Tim is 13 years old and a slightly below-average student. His main teacher, Ms. Marvel, has yet to identify any major strengths or areas of interest of Tim. As Tim and Tim's parents gave permission at the beginning of the school year for Ms. Marvel to use the "G@mes Insight for Education" (GIfE) tool, Ms. Marvel loads up the tool from her computer at work, possibly integrated through a plugin in her Moodle-like learning management system. GIfE shows Ms. Marvel an analysis of Tim's achievements (not the achievements themselves), highlighting that there seem to be accomplishments related to creativity, fluid reasoning and organizational skills. This suggests that Tim likely invested significant time into playing games that drew upon these skills and that these skills are particularly well-trained in Tim. GIfE would highlight to Ms. Marvel how these skills are related to cognitive and non-cognitive abilities relevant for academic achievement. Furthermore, GIfE would also indicate to Ms. Marvel the kinds of tasks in various school subjects that could draw upon these skills. Ms. Marvel now has a better idea of how to offer a teaching environment to Tim that is tailored to his strengths and inter- 
ests, and where Tim has unused potential. At no point would Ms. Marvel ever be able to see what games exactly Tim plays nor exactly what achievements he has earned in the video games - Ms. Marvel only has access to aggregated information based on an analysis of Tim's achievements. Tim's leisure time remains therefore protected and is not shared with Ms. Marvel. For teachers who might be interested to learn more about the games their students play in their leisure time, an option could be made available to reveal more details (e.g. the types of games played or even the names of the achievements), but strictly based on prior consent by the student in question.

In order to help Ms. Marvel understand the GIfE-tool, the ideas behind the tool and the data she is provided with, it would be crucial to offer a special training to teachers who are willing to work with such information. We think that such a training should focus on providing information on the process of translating video game achievements to skills so that teachers are able to follow the conceptual framework that lies behind this approach in more depth. Additionally, teachers could be provided with general information on competencies that are relevant for student learning and how to strengthen such skills as well as examples and materials that might help them reflect on stereotypes and deficit orientations. Additionally, the usability of the GIfE tool itself would be vital (e.g. colored bar charts for different competencies; empirical averages for every competency in the specific age group in order to be able to compare values).

In principle, such a system could make use of achievements from video games of all genres. There are myriads of ways to classify types of video games, for example in terms of represented content and game mechanics (Herz, 1997), orientation towards problem-solving or world-building (Gee, 2006) or according to the level of complexity and the extent of social interaction required (Granic et al., 2014, p. 70). So far, no classification has emerged that has been met with an overarching consensus. Likewise, no widely accepted classification of the "educational value" or even learning potential of different types of video games has emerged (Rebetez \& Betrancourt, 2007). For example, so-called first person shooter games have in the past been deemed dangerous for children and worthless with regard to their learning potential (cf. Kühl, 2016), yet there is empirical evidence suggesting that playing such games can actually enhance the ability to learn new tasks (Green \& Bavelier, 2012).

One limiting factor might be that not everyone plays video games or that different groups exhibit different playing habits. For example, there is the aforementioned evidence suggesting that children in low-SES households spend more time playing video games than in more privileged households (Carson et al., 2010). Another distinction that is frequently put forth, is that of gender. However, while there is evidence that girls tend to be interested in different types of games than boys, there is ample evidence that points to them playing about as much as boys overall (at least according to data from the producers of video games when factoring in so-called "casual" 
games such as games played on cellphones: BIU e. V. \& GfK, 2011; game - Verband der deutschen Games-Branche, 2019). In addition, one reason that girls tend to play different types of games might be because of a lack of appropriate female representation in such types (Greenberg, Sherry, Lachlan, Lucas \& Holmstrom, 2010; Lynch, Tompkins, van Driel \& Fritz, 2016). In any case, different playing habits should not affect the possibility to link achievements from video games to the possession of competencies relevant for formal education. Achievements are a common feature in video games across genres and platforms nowadays and most video game systems and platforms feature some kind of interface that allows one to share one's own achievements with others. In other words: Video game achievements could be used, regardless of (possibly) different playing habits and/or gender of the young adults playing.

\section{Conclusion}

Before a tool like the currently fictitious GIfE can become a reality, several steps are necessary. First, the necessary piece of software as well as accompanying training needs to be developed for teachers. As software that tries to translate data from selected video game achievements into information about soft skills already exists (Escribano, 2017), such an endeavour can be considered feasible from a technical standpoint. Furthermore, additional research into the correlations between certain video game activities, video game achievements and cognitive abilities is necessary, ideally using experimental settings and randomized control group designs. Additionally, studies that map achievements from popular video games to competencies that are relevant for formal education are required in order to enable data from as many games as possible to be used. Furthermore, feedback from a software tool like GIfE needs to be tailored to the teachers' needs: firstly, by showing the evidence-based link between the gaming achievements and academic achievements embedded into models of cognitive abilities (cf. CHC theory); secondly, by showing how various school subjects could draw upon these abilities. Findings from a project that worked with 40 schools in disadvantaged areas in Germany suggest that data on students' skills that challenge deficit orientations in teachers and provided schools with knowledge on students' skills and abilities was perceived as very helpful by principals and steering groups in order to create a climate for change (Drucks et al., 2019). Such feedback should be guided by experts that illustrate to teachers the potential, as well as the limits, of this data. In any case, giving teachers tools to understand how gaming achievements translate to abilities that are relevant for formal education could enable them to better connect to these students and support them on their learning journey. Furthermore, it must be ensured students' leisure gaming time is not overinstrumentalized for educational purposes. Therefore, it will be crucial that teachers don't receive any information on the games themselves, but, rather, are provided with 'translated information' on students' abilities. Some teachers have a hard time devel- 
oping positive student orientations towards low SES students (Bremm, 2019), something that could be mitigated by using data from gaming to show (the potential for) learning. Our approach could facilitate relationships and raise teacher expectations regarding students' abilities, thus, addressing some of the factors of successful learning in disadvantaged schools.

\section{References}

Anderson, C. A., \& Bushman, B. J. (2001). Effects of Violent Video Games on Aggressive Behavior, Aggressive Cognition, Aggressive Affect, Physiological Arousal, and Prosocial Behavior: A Meta-Analytic Review of the Scientific Literature. Psychological Science, 12 (5), 353-359. https://doi.org/10.1111/1467-9280.00366

Anderson, C. A., Shibuya, A., Ihori, N., Swing, E. L., Bushman, B. J., Sakamoto, A., Rothstein, H. R., \& Saleem, M. (2010). Violent Video Game Effects on Aggression, Empathy, and Prosocial Behavior in Eastern and Western Countries: A Meta-Analytic Review. Psychological Bulletin, 136 (2), 151-173. https://doi.org/10.1037/a0018251

Arnab, S., Lim, T., Carvalho, M. B., Bellotti, F., Freitas, S. de, Louchart, S., Suttie, N., Berta, R., \& De Gloria, A. (2015). Mapping Learning and Game Mechanics for Serious Games Analysis. British Journal of Educational Technology, 46 (2), 391-411. https://doi. org/10.1111/bjet.12113

Avontuur, T., \& Spronck, P. (2013). Player Skill Modeling in Starcraft II. Proceedings of the Ninth AAAI Conference on Artificial Intelligence and Interactive Digital Entertainment, $2-8$.

Baniqued, P. L., Lee, H., Voss, M. W., Basak, C., Cosman, J. D., DeSouza, S., Severson, J., Salthouse, T. A., \& Kramer, T. (2013). Selling Points: What Cognitive Abilities Are Tapped by Casual Video Games? Acta Psychologica, 142 (1), 74-86. https://doi. org/10.1016/j.actpsy.2012.11.009

Barr, M. (2017). Video Games Can Develop Graduate Skills in Higher Education Students: A Randomised Trial. Computers \& Education, 113, 86-97. https://doi.org/10.1016/j. compedu.2017.05.016

Bediou, B., Adams, D. M., Mayer, R. E., Tipton, E., Green, C. S., \& Bavelier, D. (2018). MetaAnalysis of Action Video Game Impact on Perceptual, Attentional, and Cognitive Skills. Psychological Bulletin, 144 (1), 77-110. https://doi.org/10.1037/bul0000130

Bickley, P. G., Keith, T. Z., \& Wolfle, L. M. (1995). The Three-Stratum Theory of Cognitive Abilities: Test of the Structure of Intelligence across the Life Span. Intelligence, 20 (3), 309-328. https://doi.org/10.1016/0160-2896(95)90013-6

BIU e.V. \& GfK (2011). Gamer in Deutschland 2011. Berlin: Bundesverband Interaktive Unterhaltungssoftware e. V. (BIU).

Bogost, I. (2014). Why Gamification Is Bullshit. In S. P. Walz \& S. Deterding (Eds.), The Gameful World: Approaches, Issues, Applications (pp. 65-80). Cambridge: MIT Press.

Bonefeld, M., \& Dickhäuser, O. (2018). (Biased) Grading of Students' Performance: Students' Names, Performance Level, and Implicit Attitudes. Frontiers in Psychology, 9, 481. https://doi.org/10.3389/fpsyg.2018.00481

Boot, W. R. (2015). Video Games as Tools to Achieve Insight into Cognitive Processes. Frontiers in Psychology, 6, (3). https://doi.org/10.3389/fpsyg.2015.00003

Boyle, E. A., Hainey, T., Connolly, T. M., Gray, G., Earp, J., Ott, M., Lim, T., Ninaus, M., Ribeiro, C., \& Pereira, J. (2016). An Update to the Systematic Literature Review of Empirical Evidence of the Impacts and Outcomes of Computer Games and Serious 
Pierre Tulowitzki, Nina Bremm, Chris Brown \& Georg Krammer

Games. Computers \& Education, 94, 178-192. https://doi.org/10.1016/j.compedu.2015. 11.003

Bremm, N. (2019, im Druck). Umso mehr kommt es auf die Lehrperson an - Defizitperspektiven von Lehrkräften an Schulen in sozialräumlich benachteiligten Lagen. In S. Drucks \& D. Bruland (Eds.), Kritische Lebensereignisse und die Herausforderungen für die Schule (pp. 105-126). Weinheim: Beltz Juventa.

Buck, M. F. (2017). Gamification of Learning and Teaching in Schools - A Critical Stance. Seminar.Net, 13 (1), 35-54.

Carson, V., Spence, J. C., Cutumisu, N., \& Cargill, L. (2010). Association between Neighborhood Socioeconomic Status and Screen Time among Pre-School Children: A CrossSectional Study. BMC Public Health, 10, 367. https://doi.org/10.1186/1471-2458-10-367

Castillo, S. A., Escribano, F., \& Muntada, M. (2017). XBadges. How Soft Skills Are Boosted by Video Games: Improving Persistence, Risk Taking \& Spatial Reasoning with Flappy Bird, Pacman \& Tetris. Date of access: 10.10.2019. Retrieved from http://riull.ull.es/xmlui/ handle/915/4764.

Deary, I. J., Strand, S., Smith, P., \& Fernandes, C. (2007). Intelligence and Educational Achievement. Intelligence, 35 (1), 13-21. https://doi.org/10.1016/j.intell.2006.02.001

Devers, C. J., \& Gurung, R. A. R. (2015). Critical Perspective on Gamification in Education. In T. Reiners \& L. C. Wood (Eds.), Gamification in Education and Business (pp. 417430). Cham: Springer. https://doi.org/10.1007/978-3-319-10208-5_21

Dicheva, D., Dichev, C., Agre, G., \& Angelova, G. (2015). Gamification in Education: A Systematic Mapping Study. Journal of Educational Technology \& Society, 18 (3), 75-88.

Ditton, H. (2016). Der Beitrag von Schule und Lehrern zur Reproduktion von Bildungsungleichheit. In R. Becker \& W. Lauterbach (Eds.), Bildung als Privileg: Erklärungen und Befunde $z u$ den Ursachen der Bildungsungleichheit (pp. 281-312). Wiesbaden: Springer VS. https://doi.org/10.1007/978-3-658-11952-2_9

Drucks, S., Bremm, N., van Ackeren, I., \& Klein, E. D. (2019, im Druck). Recognizing the Strengths of 'Failing Schools' - An Evidence-based Way to Sustainable Change? In C. Meyers \& M. Darwine (Eds.), School Turnaround in Secondary Schools. Possibilities, Complexities, \& Sustainability (pp. 125-147). Charlotte, NC: Information Age Publishing.

Escribano, F. (2017, May 3). Why Detecting and Training Soft Skills with Commercial Video Games Is Crucial to Meet the Challenges of the ICT Society. Date of access: 10.06.2019. Retrieved from GeCon.es Gamification Research website: https://gecon.es/soft-skillscommercial-video-games/.

Esser, H., \& Hoenig, K. (2018). Leistungsgerechtigkeit und Bildungsungleichheit: Effekte der Verbindlichkeit der Grundschulempfehlungen beim Übergang auf das Gymnasium. Ein Vergleich der deutschen Bundesländer mit den Daten der „National Educational Panel Study“ (NEPS). KZfSS Kölner Zeitschrift für Soziologie und Sozialpsychologie, 70 (3), 419-447. https://doi.org/10.1007/s11577-018-0558-2

Ferguson, C. J. (2015). Do Angry Birds Make for Angry Children? A Meta-Analysis of Video Game Influences on Children's and Adolescents' Aggression, Mental Health, Prosocial Behavior, and Academic Performance. Perspectives on Psychological Science, 10 (5), 646-666. https://doi.org/10.1177/1745691615592234

Fölling-Albers, M. (2000). Entscholarisierung von Schule und Scholarisierung von Freizeit? Überlegungen zu Formen der Entgrenzung von Schule und Kindheit. Zeitschrift für Soziologie der Erziehung und Sozialisation, 20 (2), 118-131.

Gabbiadini, A., \& Greitemeyer, T. (2017). Uncovering the Association between Strategy Video Games and Self-Regulation: A Correlational Study. Personality and Individual Differences, 104, 129-136. https://doi.org/10.1016/j.paid.2016.07.041 
game - Verband der deutschen Games-Branche (2019). Jahresreport der deutschen GamesBranche 2019. Berlin: game - Verband der deutschen Games-Branche e. V.

Gee, J. P. (2005). Learning by Design: Good Video Games as Learning Machines. E-Learning and Digital Media, 2 (1), 5-16. https://doi.org/10.2304/elea.2005.2.1.5

Gee, J. P. (2006). Are Video Games Good for Learning? Nordic Journal of Digital Literacy, 1 (3), 172-183. Date of access: 10.06.2019. Retrieved from https://www.idunn.no/dk/ 2006/03/are_video_games_good_for_learning.

Giessen, H. W. (2015). Serious Games Effects: An Overview. Procedia - Social and Behavioral Sciences, 174, 2240-2244. https://doi.org/10.1016/j.sbspro.2015.01.881

Girard, C., Ecalle, J., \& Magnan, A. (2012). Serious Games as New Educational Tools: How Effective Are They? A Meta-Analysis of Recent Studies. Journal of Computer Assisted Learning, 29 (3), 207-219. https://doi.org/10.1111/j.1365-2729.2012.00489.x

Goffman, E. (1961). Asylums: Essays on the Social Situation of Mental Patients and Other Inmates. Garden City, NY: Anchor Books.

Granic, I., Lobel, A., \& Engels, R. C. M. E. (2014). The Benefits of Playing Video Games. American Psychologist, 69 (1), 66-78. https://doi.org/10.1037/a0034857

Green, C. S., \& Bavelier, D. (2012). Learning, Attentional Control, and Action Video Games. Current Biology, 22 (6), R197-R206. https://doi.org/10.1016/j.cub.2012.02.012

Greenberg, B. S., Sherry, J., Lachlan, K., Lucas, K., \& Holmstrom, A. (2010). Orientations to Video Games among Gender and Age Groups. Simulation \& Gaming, 41 (2), 238-259. https://doi.org/10.1177/1046878108319930

Greitemeyer, T., \& Mügge, D. O. (2014). Video Games Do Affect Social Outcomes: A Meta-Analytic Review of the Effects of Violent and Prosocial Video Game Play. Personality and Social Psychology Bulletin, 40 (5), 578-589. https://doi.org/10.1177/ 0146167213520459

Helbig, M., \& Morar, T. (2018). Why Teachers Assign Socially Unequal Marks. A Case for Establishing Tertiary Origin Effects in the Model of Primary and Secondary Effects of Educational Research. International Journal of Learning, Teaching and Educational Research, 17 (7), 1-25. https://doi.org/10.26803/ijlter.17.7.1

Herz, J. C. (1997). Joystick Nation: How Videogames Ate Our Quarters, Won Our Hearts, and Rewired Our Minds. Boston, MA: Little, Brown \& Company.

Ifenthaler, D., Bellin-Mularski, N., \& Mah, D.-K. (Eds.). (2016). Foundation of Digital Badges and Micro-Credentials. Cham: Springer. https://doi.org/10.1007/978-3-319-15425-1

Kaiser, J., Möller, J., Helm, F., \& Kunter, M. (2015). Das Schülerinventar: Welche Schülermerkmale die Leistungsurteile von Lehrkräften beeinflussen. Zeitschrift für Erziehungswissenschaft, 18 (2), 279-302. https://doi.org/10.1007/s11618-015-0619-5

Kühl, E. (2016, February 5). „Killerspiele“: Und wenn sie nicht gestorben sind, diskutieren sie noch heute. Die Zeit. Date of access: 10.10.2019. Retrieved from https://www.zeit. de/digital/games/2016-02/killerspiele-gewalt-game-dokumentation-zdf.

Kühn, S., Gleich, T., Lorenz, R. C., Lindenberger, U., \& Gallinat, J. (2014). Playing Super Mario Induces Structural Brain Plasticity: Gray Matter Changes Resulting from Training with a Commercial Video Game. Molecular Psychiatry, 196 (2), 265-271. https:// doi.org/10.1038/mp.2013.120

Landers, R. N. (2014). Developing a Theory of Gamified Learning: Linking Serious Games and Gamification of Learning. Simulation \& Gaming, 45 (6), 752-768. https://doi. org/10.1177/1046878114563660

Lewis, I., Salas, K. de, \& Wells, L. (2013). Features of Achievement Systems. 2013 18th International Conference on Computer Games: AI, Animation, Mobile, Interactive Multimedia, Educational Serious Games (CGAMES), 66-73. https://doi.org/10.1109/ CGames.2013.6632608 
Pierre Tulowitzki, Nina Bremm, Chris Brown \& Georg Krammer

Lorenz, G., Gentrup, S., Kristen, C., Stanat, P., \& Kogan, I. (2016). Stereotype bei Lehrkräften? Eine Untersuchung systematisch verzerrter Lehrererwartungen. KZfSS Kölner Zeitschrift für Soziologie und Sozialpsychologie, 68 (1), 89-111. https://doi.org/10.1007/ s11577-015-0352-3

Lynch, T., Tompkins, J. E., van Driel, I. I., \& Fritz, N. (2016). Sexy, Strong, and Secondary: A Content Analysis of Female Characters in Video Games across 31 Years. Journal of Communication, 66 (4), 564-584. https://doi.org/10.1111/jcom.12237

McGrew, K. S. (2009). CHC Theory and the Human Cognitive Abilities Project: Standing on the Shoulders of the Giants of Psychometric Intelligence Research. Intelligence, 37 (1), 1-10. https://doi.org/10.1016/j.intell.2008.08.004

McPherson, J., \& Burns, N. R. (2005). A Speeded Coding Task Using a Computer-based Mouse Response. Behavior Research Methods, 37 (3), 538-544. https://doi.org/10.3758/ BF03192725

Moisala, M., Salmela, V., Hietajärvi, L., Carlson, S., Vuontela, V., Lonka, K., Hakkarainen, K., Salmela-Aro, K., \& Alho, K. (2017). Gaming Is Related to Enhanced Working Memory Performance and Task-related Cortical Activity. Brain Research, 1655, 204215. https://doi.org/10.1016/j.brainres.2016.10.027

Oei, A.C., \& Patterson, M. D. (2014). Playing a Puzzle Video Game with Changing Requirements Improves Executive Functions. Computers in Human Behavior, 37, 216228. https://doi.org/10.1016/j.chb.2014.04.046

Ofcom (Office of Communications) (2017). Children and Parents: Media Use and Attitudes Report. Research Report. London: Ofcom.

Pallavicini, F., Ferrari, A., \& Mantovani, F. (2018). Video Games for Well-Being: A Systematic Review on the Application of Computer Games for Cognitive and Emotional Training in the Adult Population. Frontiers in Psychology, 9. https://doi. org/10.3389/fpsyg.2018.02127

Peng, W., Lin, J.-H., \& Crouse, J. (2011). Is Playing Exergames Really Exercising? A MetaAnalysis of Energy Expenditure in Active Video Games. Cyberpsychology, Behavior, and Social Networking, 14 (11), 681-688. https://doi.org/10.1089/cyber.2010.0578

Poropat, A. E. (2009). A Meta-Analysis of the Five-Factor Model of Personality and Academic Performance. Psychological Bulletin, 135 (2), 322-338. https://doi.org/10. 1037/a0014996

Primack, B. A., Carroll, M. V., McNamara, M., Klem, M. L., King, B., Rich, M., Chan, C. W., \& Nayak, S. (2012). Role of Video Games in Improving Health-Related Outcomes. American Journal of Preventive Medicine, 42 (6), 630-638. https://doi.org/10.1016/j. amepre.2012.02.023

Quiroga, M. A., Román, F. J., De La Fuente, J., Privado, J., \& Colom, R. (2016). The Measurement of Intelligence in the XXI Century using Video Games. The Spanish Journal of Psychology, 19. https://doi.org/10.1017/sjp.2016.84

Racherbäumer, K. (2017). Rekonstruktionen zu Bedeutung und Funktionen der LehrerSchüler-Beziehung aus Sicht von Lehrerinnen und Lehrern an Schulen in sozial benachteiligter Lage. In V. Manitius \& P. Dobbelstein (Eds.), Schulentwicklungsarbeit in herausfordernden Lagen (pp. 123-139). Münster \& New York: Waxmann.

Rebetez, C., \& Betrancourt, M. (2007). Video Game Research in Cognitive and Educational Sciences. Cognition, Brain, Behavior, 131-142.

Richardson, M., Abraham, C., \& Bond, R. (2012). Psychological Correlates of University Students' Academic Performance: A Systematic Review and Meta-Analysis. Psychological Bulletin, 138 (2), 353-387. https://doi.org/10.1037/a0026838

Roque, N. A., \& Boot, W. R. (2018). Action Video Games DO NOT Promote Visual Attention. In C. J. Ferguson (Ed.), Video Game Influences on Aggression, Cognition, and Attention (pp. 105-118). Cham: Springer. https://doi.org/10.1007/978-3-319-95495-0_9 
Sala, G., Tatlidil, K. S., \& Gobet, F. (2018). Video Game Training Does Not Enhance Cognitive Ability: A Comprehensive Meta-Analytic Investigation. Psychological Bulletin, 144 (2), 111-139. http:///doi.org/10.1037/bul0000139

Shaffer, D. W., Squire, K. R., Halverson, R., \& Gee, J. P. (2005). Video Games and the Future of Learning. Phi Delta Kappan, 87 (2), 105-111. https://doi.org/10.1177/ 003172170508700205

Sorhagen, N. S. (2013). Early Teacher Expectations Disproportionately Affect Poor Children's High School Performance. Journal of Educational Psychology, 105 (2), 465477. https://doi.org/10.1037/a0031754

Valadez, J. J., \& Ferguson, C. J. (2012). Just a Game after All: Violent Video Game Exposure and Time Spent Playing Effects on Hostile Feelings, Depression, and Visuospatial Cognition. Computers in Human Behavior, 28 (2), 608-616. https://doi.org/10.1016/j. chb.2011.11.006

Valencia, R. R. (Ed.). (1997). The Evolution of Deficit Thinking: Educational Thought and Practice. London: The Falmer Press.

Waller, G., Willemse, I., Genner, S., Suter, L., \& Süss, D. (2016). JAMES - Jugend, Aktivitäten, Medien - Erhebung Schweiz. Zürich: Zürcher Hochschule für Angewandte Wissenschaften.

Pierre Tulowitzki, Jun.-Prof. Dr., born 1982, Junior Professor and Head of the Department of International Educational Leadership and Management at the Ludwigsburg University of Education, Germany.

Address: Ludwigsburg University of Education, Reuteallee 46, 71634 Ludwigsburg, Germany

E-mail: tulowitzki@ph-ludwigsburg.de

Nina Bremm, Dr., born 1979, Professor for School Improvement at the Zurich University of Teacher Education, Switzerland.

Address: PH Zürich, Lagerstrasse 2, 8090 Zürich, Switzerland

E-mail: nina.bremm@phzh.ch

Chris Brown, Prof. Dr., born 1975, Professor in Education at the School of Education, Durham University, England.

Address: School of Education, Durham University, Leazes Road, Durham, DH1 1TA, Great Britain

E-mail: chris.brown@durham.ac.uk

Georg Krammer, HS-Prof. Dr., born 1988, University College Professor for Educational Measurement and Applied Psychometrics at the University College of Teacher Education Styria, Austria.

Address: Georg Krammer, University College of Teacher Education Styria, Hasnerplatz 12, 8010 Graz, Austria

E-mail: georg.krammer@phst.at 